\title{
PENGARUH KOMPETENSI SDM DAN SISTEM AKUNTANSI KEUANGAN DAERAH TERHADAP KUALITAS LAPORAN KEUANGAN DAERAH
}

\author{
Abdul Rahman ${ }^{1}$, Ayudhini Azzahra Permatasari²
}

\begin{abstract}
The purpose of this article is to determine the impact of human resource skills and financial accounting systems on the quality of regional financial statements. Using quantitative methods for accounting or financial personnel management at government offices in Buleleng regional, this study shows that human resource literacy and the financial system have a positive and significant impact on the quality of regional financial systems reported. Thus, the results of this study indicate the need to increase human resources for financial management in the regions and the financial accounting system in accordance with established standards.
\end{abstract}

Keywords: Competency of Human Resources; regional financial accounting system; quality of regional financial reports.

\section{PENDAHULUAN}

Dewasa ini tuntutan masyarakat semakin meningkat atas pemerintahan yang baik. Kinerja Satuan Kerja Perangkat Daerah (SKPD) harus ditingkatkan agar menghasilkan laporan keuangan yang berkualitas. Laporan keuangan adalah suatu cerminan untuk dapat mengetahui apakah suatu pemerintahan telah berjalan dengan baik sehingga pemerintah diharuskan untuk dapat menghasilkan laporan keuangan yang berkualitas. Di mana laporan keuangan yang dihasilkan telah memenuhi karakteristik kualitatif laporan keuangan yang terdiri dari relevan, andal, dapat dibandingkan, dan dapat dipahami.

Tuntutan masyarakat kepada pemerintahan adalah dihasilkannya laporan keuangan yang telah memenuhi ke empat karakteristik kualitas laporan keuangan tersebut. Laporan keuangan adalahsuatu alat pertanggungjawaban atas kinerja keuangan manajemen suatu pemerintahan kepada publik yang dipercayakan kepadanya (Prasetya, 2005). Informasidalam laporan keuangan banyak dimanfaatkan oleh pihakpihak yang berkepentingan. Di mana pihak-pihak yang berkepentingan tersebut

\footnotetext{
${ }^{1}$ Politeknik STIA LAN Bandung

${ }^{2}$ Politeknik STIA LAN Bandung
} 
menggunakan informasi yang terdapat dalam laporan keuangan untuk mengambil suatu keputusan. Keputusan yang dihasilkan diharapkan dapat membawa pemerintahan ke arah yang lebih baik.

Laporan keuangan adalah produk yang dihasilkan oleh disiplin ilmu akuntansi sehingga untuk menghasilkan laporan keuangan diperlukan orang-orang yang berkompeten. Kompetensi sumber daya manusia sangat diperlukan agar laporan keuangan yang dihasilkan dapat memenuhi karakteristik kualitatif laporan keuangan sehingga laporan keuangan yang dihasilkan dapat berkualitas danbermanfaat dalam hal pengambilan keputusan. Sumber daya manusia adalah faktor penting demi terciptanya laporan keuangan yang berkualitas. Keberhasilan suatu entitas bukan hanya dipengaruhi oleh sumber daya manusia yang dimilikinya melainkan kompetensi sumber daya manusia yang dimilikinya. Dalam hal ini kompetensi sumber daya manusia memiliki peranan yang sangat penting untuk merencanakan, melaksanakan, dan mengendalikan entitas yang bersangkutan.

Kompetensi adalah ciri seseorang yang dapat dilihat dari keterampilan, pengetahuan, dan kemampuan yang dimilikinya dalam hal menyelesaikan tugas-tugas yang dibebankan kepadanya (Hervesi, 2005 dalam Indriasari 2008). Kompetensi merupakan dasar seseorang untuk mencapai kinerja tinggi dalam menyelesaikan kinerjanya. Sumber daya manusia yang tidak memiliki kompetensi tidak akan dapat menyelesaikan pekerjaannya secara efisien, efektif, dan ekonomis. Dalam hal ini pekerjaan yang dihasilkan tidak akan tepat waktu dan terdapat pemborosan waktu serta tenaga. Dengan adanya kompetensi sumber daya manusia maka waktu pembuatan laporan keuanganakan dapat dihemat. Hal ini karena sumber daya manusia tersebut telah memiliki pengetahuan dan pemahaman mengenai hal-hal yang harus dikerjakan sehingga laporan keuangan yang disusun dapat diselesaikan dan disajikan tepat pada waktunya. Semakin cepat laporan keuangan disajikan maka akan semakin baik dalam hal pengambilan keputusan (Mardiasmo, 2002: 146).

Selain itu, dalam penyusunan laporan keuangan juga diperlukan sistem akuntansi. Di mana untuk menghasilkan laporan keuangan daerah dibutuhkan suatu sistem akuntansi keuangan daerah. Sistem akuntansi keuangan daerah (SAKD) merupakan suatu prosedur dari tahap awal pengumpulan data sampai pelaporan keuangan atas pertanggungjawaban pelaksanaan APBD(Permendagri No. 59 Tahun 
2007). Jika sistem akuntansi belum dipahami maka akan dapat menghambat dalam penyusunan laporan keuangan. Pemerintah telah berupaya untuk menyusun laporan berdasarkan sistem akuntansi keuangan daerah sehingga kualitas yang dihasilkan dari laporankeuangan daerah tersebut dapat meningkat. Namun kenyataannya tidak semua pegawai di pemerintahan memahami sistem akuntansi keuangan daerah tersebut.

Kenyataan di dalam laporan keuangan pemerintah daerah masih banyak disajikan data-data yang tidak sesuai dan tidak mengikuti prinsip akuntansi berlaku umum. Banyak laporan keuangan yang mendapatkan opini tidak wajar dan disclaimer karena dalam penyusunannya belum sesuai denganstandar yang telah ditetapkan dan belum memenuhi kelengkapan yang telah ditentukan serta kurangnya bukti-bukti transaksi yang dapat ditemukan. Penulisan ini menambahkan variabel kompetensi sumber daya manusia dan penerapan sistem akuntansi keuangan daerah sebagai variabel independen serta menguji pengaruhnya terhadap kualitas laporan keuangandaerah.

Berdasarkan uraian tersebut dapat dikatakan bahwa kompetensi sumber daya manusia dan sistem akuntansi keuangan daerah menjadi faktor penting dalam menghasilkan laporan keuangan yang berkualitas. Di mana apabila kualitas laporan keuangan telah terpenuhi maka pemerintahan yang baik akan dapat tercapai. Dengan demikian, berdasarkan latar belakang yang telah dikemukakan di atas maka rumusan masalah dalam penulisan ini adalah 1) "Apakah kompetensi sumber daya manusia dan sistem akuntansi keuangan daerah secara parsial berpengaruh positif dan signifikan terhadap kualitas laporan keuangan daerah Kabupaten Buleleng?" 2) “Apakah kompetensi sumber daya manusia dan sistem akuntansi keuangan daerah secara simultan berpengaruh signifikan erhadap kualitas laporan keuangan daerah Kabupaten Buleleng?"

Dalam rangka menjawab permasalahan tersebut penulisan ini bertujuan untuk mengetahui pengaruh variabel kompetensi sumber daya manusia pada kualitas laporan keuangan daerah Kabupaten Buleleng, pengaruh variabel sistem akuntansi keuangan daerah pada kualitas laporan keuangan daerah Kabupaten Buleleng. Hasil penulisan ini sangat bermanfaat, yaitu: pertama, manfaat teoritis adalah dengan adanyapenulisan ini, mahasiswa diharapkan dapat mengetahui faktor-faktor yang mempengaruhi kualitas laporan keuangan, yaitu kompetensi sumber daya manusia dan sistem akuntansi keuangan daerah. Kedua, manfaat praktis adalah dengan hasil penulisanini diharapkan dapat digunakan sebagai masukan dan saran-saran serta dapat digunakan sebagai salah 
satu sarana dalam meningkatkan kualitas laporan keuangan daerah di waktu yang akan datang.

\section{METODE PENELITIAN}

Studi ini menggunakan metode penelitian kuantitatif dengan populasi adalah pegawai bagian akuntansi atau penatausahaan keuangan di SKPD yang meliputi dinas, badan, dan kantor di Pemerintahan Kabupaten Buleleng. Pemilihan kabupaten Buleleng didasarkan karena prestasi kabupaten ini dalam pengelolaan pemerintahan termasuk pada sektor keuangan. Jumlah pegawai akuntansi atau penatausahaan keuangan yang menjadi populasi dalam penelitian ini adalah 369 orang dari 28 SKPD yang tersebar di wilayah Kabupaten Buleleng. Dengan menggunakan rumus Slovin dan tingkat error atau kesalahan yang diterima 5\% didapatkan 95 sampel untuk studi in. Data yang diperoleh dari Kuesioner kemudian diolah dengan menggunakan Analisis Regresi Berganda yang ada pada aplikasi SPSS Ver.17.

\section{HASIL DAN PEMBAHASAN}

Pengujian validitas dan reliabilitas dilakukan terhadap item kuesioner pada penelitian ini. Hasilnya, uji validitas menunjukkan bahwa $r$ hitung $>r$ tabel $=0,1184$, sehingga masing-masing itemkuesioner dianggap valid. Selanjutnya, hasil uji reliabilitas menunjukkan bahwa alpha cronbach untuk keempat variabel lebih besar dari 0,7. Hal ini berarti kuesioner yang digunakan dikatakan reliabel.

Terkait pengujian regresi berganda, hasil uji normalitas menunjukkan bahwa model regresiberdistribusi normal karena lebih besar dari 0,05. Hal ini dapat dilihat pada gambar 1.1. 


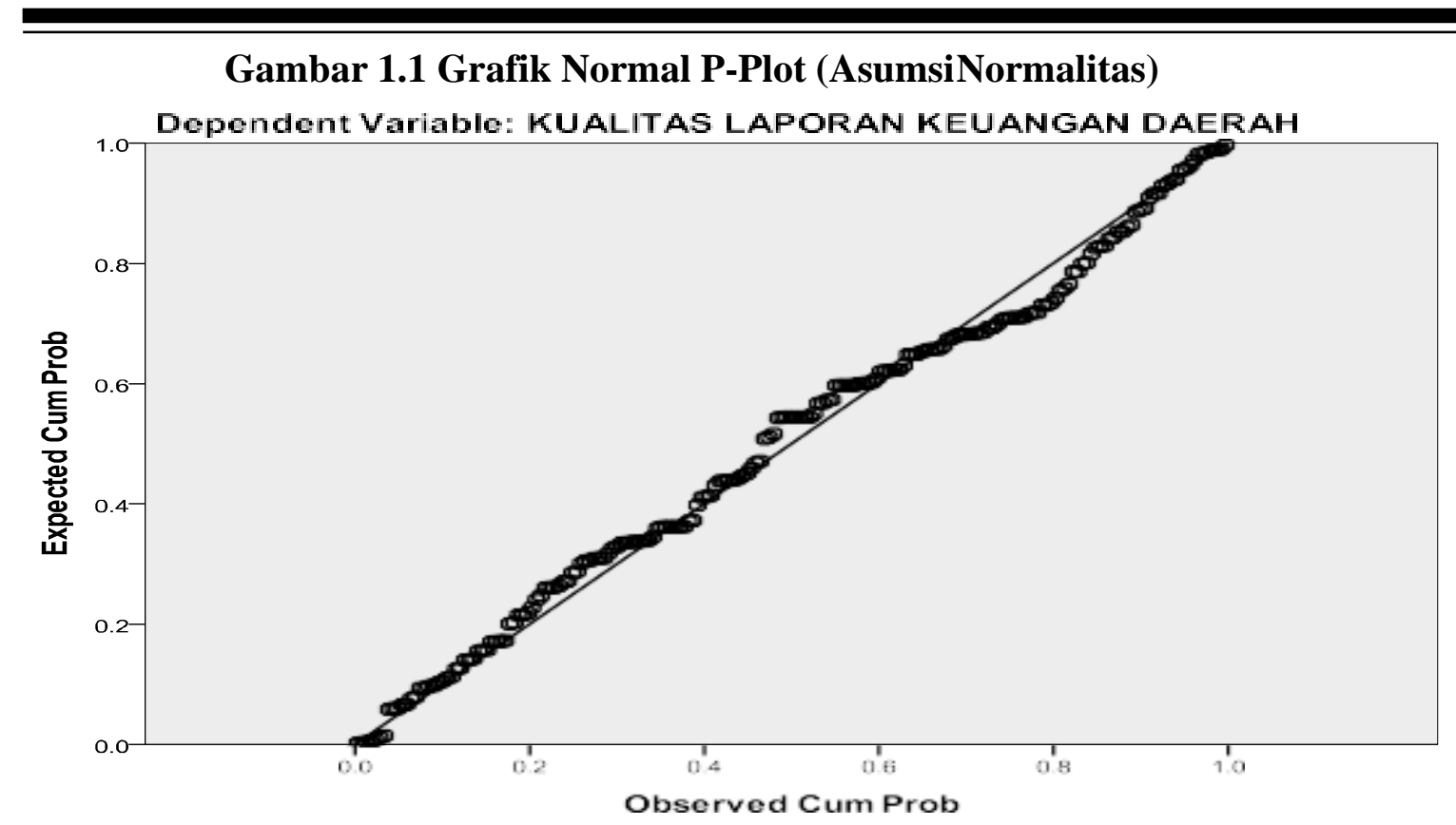

Dalam penelitian ini juga tidak terjadi multikolinearitas antar ketiga variabel karena nilai VIF kurang dari 10 dan lebih besar dari 0,10 .

\section{Gambar 1.2 Grafik Uji Heteroskedastisitas}

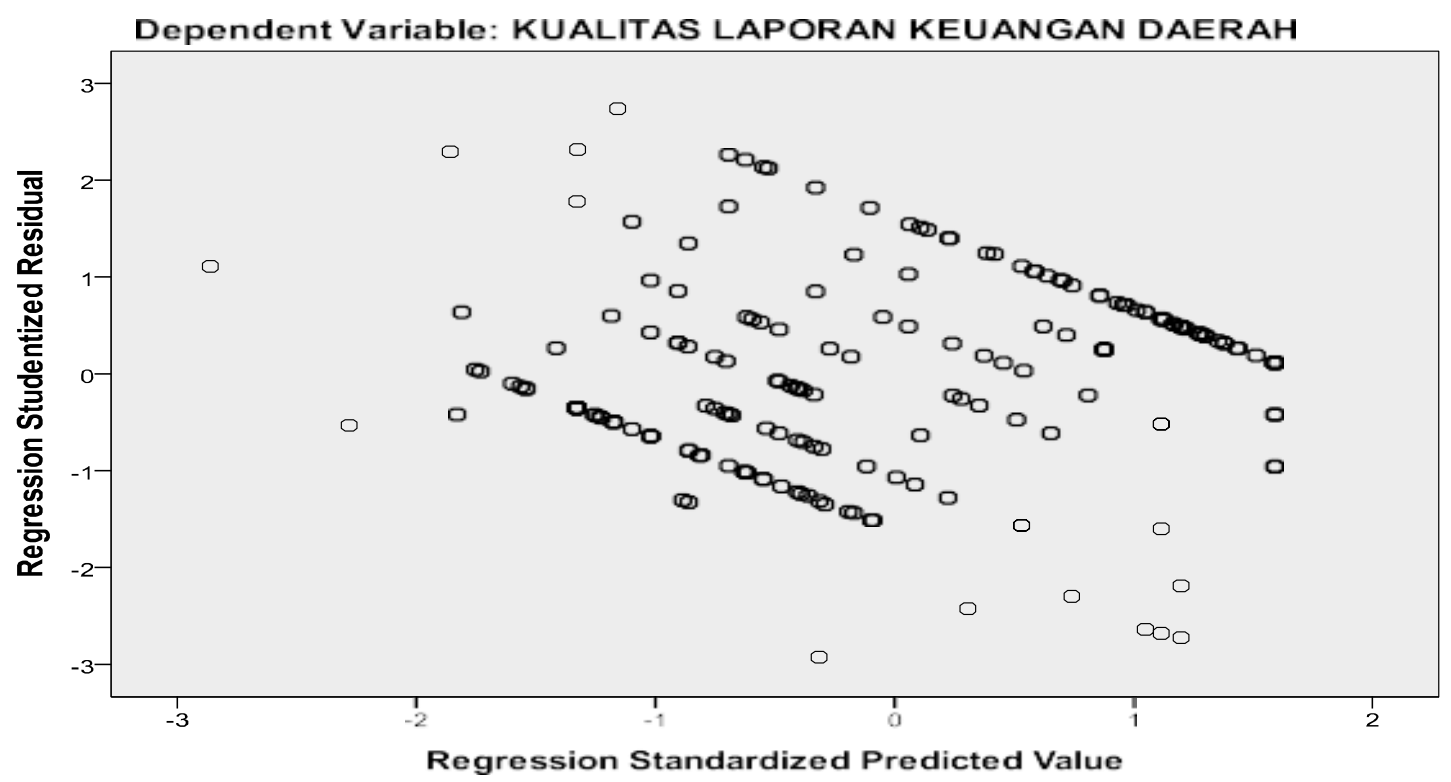

Berdasarkan hasil uji heteroskedastisitas menunjukkan bahwa dalam model regresi linier beganda tidak terjadi heteroskedastisitas. Hal ini dilihat dari probabilitas (sig) di atas 0,05. Hasil uji heteroskedastisitas dapat lihat pada gambar 1.2. 
Hasil regresi berganda dapat dilihat pada table 1 di bawah ini:

Tabel 1. Hasil Regresi Linier Berganda

\begin{tabular}{|c|c|c|c|c|c|c|}
\hline & \multirow[b]{2}{*}{ Model } & \multicolumn{2}{|c|}{$\begin{array}{l}\text { Unstandardized } \\
\text { Coefficients }\end{array}$} & \multirow{2}{*}{$\begin{array}{c}\text { Standardized } \\
\text { Coefficients } \\
\text { Beta }\end{array}$} & \multirow[b]{2}{*}{$\mathrm{T}$} & \multirow[b]{2}{*}{ Sig. } \\
\hline & & B & $\begin{array}{l}\text { Std. } \\
\text { Error }\end{array}$ & & & \\
\hline \multirow[t]{9}{*}{1} & (Constant) & 14,169 & 1,900 & & 7.457 & .000 \\
\hline & Kompetensi SDM & 139 &, 062 & 141 & 2,239 &, 026 \\
\hline & Penerapan SAP & 372 & .037 & 558 & 9,978 &, 000 \\
\hline & $\begin{array}{l}\text { Sistem Akuntansi } \\
\text { Keuangan Daerah }\end{array}$ &, 135 &, 058 &, 149 & 2,328 &, 021 \\
\hline & $\mathrm{R}$ & $.685^{a}$ & & & & \\
\hline & $\mathrm{R}^{2}$ & 469 & & & & \\
\hline & Adjusted $\mathrm{R}^{2}$ & 460 & & & & \\
\hline & F hitung & 56,148 & & & & \\
\hline & Signifikansi F & $.000^{3}$ & & & & \\
\hline
\end{tabular}

Sumber: Data Diolah

Tabel 1 memberikan informasi terkait signifikasi pengaruh dari masing-masing variable independen yaitu Kompetensi SDM dan Sistem Akuntansi Keuangan Daerah (Penerapan SAP) terhadap variable dependen, yaitu Kualitas laporan keuangan daerah (Sistem Akuntansi Keuangan Daerah) serta pengaruhnya secara simultan.

\section{Pengaruh Kompetensi Sumber Daya Manusia Terhadap Kualitas Laporan Keuangan Daerah}

Merujuk pada tabel 1 maka didapatkan nilai signifikansi untuk variable Kompetensi SDM sebesar 0,026, di bawah nilai sig 0,05 artinya terdapat pengaruh yang significant dari kompetensi sumber daya manusia terhadap kualitas laporan keuangan daerah. Hasil penelitian ini sejalan dengan penelitian yang dilakukan oleh Ropiyantie (2012) yang menemukan bahwa kompetensi sumber daya manusia memiliki pengaruh yang signifikan terhadap kualitas laporan keuangan daerah. Hal ini karena dengan adanya kompetensi sumber daya manusia maka peranan dalam merencanakan, melaksanakan, dan mengendalikan organisasi akan berjalan dengan baik serta kegiatan dapat diselesaikan secara profesional, efektif dan efisien.

Jika kompetensi sumber daya manusia dilaksanakan dengan baik maka kualitas laporan keuangan daerah akan meningkat sehingga laporan keuangan yang baik dapat memenuhi karakteristik kualitatif laporan keuangan. Dengan demikian kompetensi sumber daya manusia ditunjukkan agar penyelenggaraan tugas dan fungsi organisasi dalam rangka menghasilkan laporan keuangan daerah yang berkualitas dapat diterapkan. 
Jadi dengan adanya kompetensi sumber daya manusia dapat diketahui apakah suatu pemerintahan telah melaksanakan tugas dan fungsinya secara profesional, efektif, dan efisien sehingga dengan adanya kompetensi sumber daya manusia mendorong terwujudnya laporan keuangan yang berkualitas yang bebas dari salah saji material dan pengertian yangmenyesatkan.

\section{Pengaruh Sistem Akuntansi Keuangan Daerah Terhadap Kualitas Laporan Keuangan Daerah}

Tabel 1 menginformasikan nilai signifikansi untuk variable Sistem akuntansi keuangan daerah (Penerapan SAP) sebesar 0,000, di bawah nilai sig 0,05 artinya terdapat pengaruh yang significant dari Sistem akuntansi keuangan daerah (penerapan SAP) terhadap kualitas laporan keuangan daerah. Hasil penelitian ini sejalan dengan penelitian yang dilakaukan oleh Ropiyantie (2012) danSihombing (2011) yang menemukan bahwa sistem akuntansi keuangan daerah berpengaruh positif dan signifikan terhadap kualitas laporan keuangan daerah. Sistem akuntansi keuangan daerah merupakan suatu prosedur dari tahap awal pengumpulan data sampai dengan dilakukannya pelaporan keuangan atas pertanggungjawaban pelaksanaan APBD (Permendagri No. 59 Tahun 2007). Jika sistem akuntansi belum dipahami maka akan dapat menghambat dalam penyusunan laporan keuangan.

Sistem akuntansi keuangan daerah adalah serangkaian prosedur untuk menyusun laporan keuangan. Informasi yang terdapat dalam laporan keuangan digunakan oleh pihak-pihak tertentu dalammengambil suatu keputusan. Kebijakan akuntansi keuangan daerah digunakan dalam penerapan sistem akuntansi keuangan daerah. Dalam menerapkan sistem akuntansi keuangan daerah digunakan kebijakan akuntansi agar dapat mengatur perlakuan akuntansi. Dengan adanya perlakuan akuntansi tersebut maka akan dapat menjamin konsistensi penyajian keuangan daerah yang dihasilkan. Kebijakan akuntansi yang dilakukan tersebut harus mengikuti standar akuntansi keuangan pemerintah daerah yang berlaku (Kepmendagri No.29 Tahun 2002).

Selain menerapkan standar akuntansi pemerintahan, sistem akuntansi keuangan daerah jugaharus diterapkan untuk menghasilkan laporan keuangan yang berkualitas. Pemahaman terhadap sistem akuntansi keuangan daerah sangat diperlukan dalam menyusun laporan keuangan agar laporan keuangan yang dihasilkan sesuai dengan karakteristik kualitatif laporan keuangan dan tidak mengandung salah saji material. Jadi 
dengan diterapkannya sistem akuntansi keuangan daerah maka akan dapat meningkatkan kualitas laporan keuangan daerah.

Bila merujuk pada hasil nilai pengaruh simultan variable Kompetensi SDM dan variable Sistem akuntansi keuangan daerah (penerapan SAP) didapatkan nilai signifikansi sebesar, 0,021. Nilai ini di bawah nilai sig 0,05 artinya terdapat pengaruh yang significant secara simultan bersama-sama variable Kompetensi sumber daya manusia dan Sistem akuntansi keuangan daerah (pelaksanaan SAP) terhadap kualitas laporan keuangan daerah. Hasil ini sesuai dengan penelitian sebelumnya yang dilakukan oleh Pujanira dan Taman (2017) dan mengindikasikan bahwa penerapan standar akuntansi pemerintahan yang baik (sistem akuntansi keuangan daerah) yang didukung oleh kompetensi sumber dayamanusia yang baik pula akan melahirkan laporan keuangan daerah yang berkualitas. Kontribusi Kompetensi SDM dan sistem akuntansi keuangan daerah mencapai hampir 50 persen (46\%) untuk peningkatan kualitas laporan keuangan daerah.

\section{KESIMPULAN}

Berdasarkan hasil temuanpenelitian dan penelusuran yang telah ditemukan dapat ditarik beberapa kesimpulan, yaitu: pertama, kompetensi sumber daya manusia berpengaruh positif dan signifikan terhadap kualitas laporan keuangan daerah. Kedua, sistem akuntansi keuangan daerah berpengaruh positif dan signifikan terhadap kualitas laporan keuangan daerah. Ketiga, Kompetensi sumber daya manusia dan sistem akuntansi keuangan daerah secara bersama-sama berpengaruh signifikan terhadap kualitas laporan keuangan daerah. Dengan kontribusi hampir 50\% variable Independen secara simultan terhadap variable Dependen, studi ini merekomendasikan pentingnya peningkatan kualitas SDM terutama bidang keuangan dan penerapan Laporan Keuangan Daerah sesuai dengan standar yang ditetapkan oleh pemerintah.

\section{DAFTAR PUSTAKA}

Indriasari, D., \& Nahartyo, E. (2009). Pengaruh kapasitas SDM, Pemanfaatan Teknologi Informasi dan Pengendalian Intern Akuntansi terhadap Keterandalan dan Ketepatwaktuan Pelaporan Keuangan Pemerintah Daerah, Studi pada Pemerintah kota Palembang dan Kabupaten Ogan Ilir. Jurnal Akuntansi.

Kusumah, Arif Ardi. (2012). Pengaruh Penerapan Sistem Akuntansi Pemerintahan terhadap Kualitas laporan Keuangan (Survei pada SKPD/OPD Pemerintahan Kota Tasikmalaya). Jurnal Accounting. Vol 1, No. 1. 
Mardiasmo. (2002). Akuntansi Sektor Publik. Yogyakarta: Andi.

Prasetya, Gede Edy. (2005). Penyusunan dan Analisis Laporan Keuangan Pemerintah Daerah. Yogyakarta: Andi.

Pujanira, Putriasri dan Abdullah Taman. (2017). Pengaruh Kompetensi Sumber Daya Manusia, Penerapan Standar Akuntansi Pemerintahan, Dan Penerapan Sistem Akuntansi Keuangan Daerah Terhadap Kualitas Laporan Keuangan Pemerintah Daerah Provinsi. Jurnal Nominal, Vol 6, No 2.

Republik Indonesia. Keputusan Menteri Dalam Negeri Nomor 29 Tahun 2002 tentang Pedoman Pengurusan, Pertanggungjawaban dan Pengawasan Keuangan Dan Belanja Daerah, Pelaksanaa Tata Usaha Keuangan daerah dan Penyusunan Perhitungan Anggaran Pendapatan Belanja Daerah.

------Peraturan Menteri Dalam Negeri Nomor 59 Tahun 2007 Tentang Perubahan Atas Peraturan Menteri Dalam Negeri Nomor 13 Tahun 2006 Tentang Pedoman Pengelolaan Keuangan Daerah.

------Peraturan Pemerintah No. 71 Tahun 2010tentang Standar Akuntansi Pemerintahan.

Ropiyantie, Devi. (2012). Pengaruh Kompetensi Sumber Daya Manusia dan Penerapan Sistem Akuntansi Keungan Daerahterhadap Kualitas laporan Keuangan Daerah (Survei pada Organisasi PerangkatDaerah (OPD) Kabupaten Tasikmalaya). Jurnal Accounting. Vol 1, No. 1.

Sugiyono. (2012). Metode Penelitian Pendidikan (Pendekatan Kuantitatif, Kualitatif, dan $R \& D)$. Bandung: Alpabeta.

Wirawan, Nata. (2002). Cara Mudah Memahami Statistik 2 (Statistik Inferensia) Untuk Ekonomi dan Bisnis. Edisi ke-2. Denpasar: Keraras Emas. http//www.bpk.go.id. Diakses 31 Oktober 2020. 